\title{
Challenges of the Nigerian Banking Sector and the Way Forward
}

\author{
Ibrahim Aliyu Gololo \\ Department of Accounting \\ Faculty of Social and Management Science \\ Bauchi State University Gadau, Bauchi, Nigeria \\ Tel:+234 8036312938/08026903796 \\ Email: aliyugololo2@gmail.com
}

Received: December 1, 2018

Accepted: December 10, 2018

Online Published: December 14, 2018

\begin{abstract}
Nigerian banking sector struggle with challenges in the day to day running of their business activities, challenges are enormous and can either be market or operational challenges and regulatory or reforms challenges instituted by the regulatory agencies such as CBN, NDIC, SEC and CIBN etc. Therefore, this paper seeks to examine the challenges facing the Nigerian banking sector and proper possible solutions to the challenges based on the prevailing economic environment. The paper utilized questionnaires as source of data collection, fifteen out of 24 banks were selected based on purposive sampling method. Chi-Square $\left(\mathrm{x}^{2}\right)$ method was adopted as a statistical tool of data analysis to analyze the collected data. The result reveals that myriad of challenges exist in the Nigerian banking sector some of which are challenges both within and outside Nigeria. Banks are left behind in technological innovation aspect of banking transactions, movement of high volume of deposit or capital flight to foreign banks by the political class which reduce banks opportunity to expand their market base and the prevalent of fraud in the sector also hinders the banks progress, these challenges affects the sector to compete equally with banking sector in the developed nations. However, we also found that the challenges does not affect their financial performance. It is recommended that that government and relevant regulatory agencies should put heads together to render support and address those challenges identified that affect the sector, also Nigerian banking sector should invest in both technological innovation and human capital development, they should imbibe the culture of good corporate governance and stick to the issue of banking ethics and professionalism among others.
\end{abstract}

\section{Keywords: Banking Sector, Challenges, Nigeria, Nigerian Economy.}

\section{Introduction}

The banking sector of any nation is important to the size of its economy. Banking system occupies a unique position in every economy [Kanayo \& Micheal, 2011]. Nigerian economy is not an exception. Most of the developing economy places more responsibilities on the banking sector to support the economic activities of the nation. Example banks are expected to mobilize the needed capital to facilitate production, generate employment and income. An economy that does not experience growth on sustained basis is likely to have a very passive financial sector as there are no incentives for investment [Basil, 2013].

Through the process of growth, banking system offers a wide range of portfolio options for savers and issuable instruments for investors, a function often referred to as financial intermediation. Banks are known to be one of the major player in the money market, they perform very important role of intermediation, whereby ensuring mobilization of idle funds from the surplus sector of the Nigerian economy to the deficit sector. They also help government to implement monetary policy through issuance of treasury bills and government bonds. It is generally recognized worldwide that the banking sector plays a catalyst role in the process of economic development [Ekundayo 2011], as such banking sector of any nation is a function of the size of its economy. A developing economy places more responsibilities on the banking sector to mobilize the needed capital to facilitate production, generate employment and income. Researchers have argued that financial sector challenges should be promptly addressed so as to avoid financial fragility that may lead to deterioration of economic activities. To ensure challenges and proper practices are carry out the government came up with regulatory agencies such as NDIC, SEC, CBN and NSE and they came up with several reforms agenda in order to strengthen not only banking sector but the whole financial sector of the country. Since independence, the Nigerian financial system is made up of financial institutions, such as banks, insurance companies, specialized 
banks, capital market, finance companies, discount houses, bureau de change, mortgage institutions, community banks, and the development finance institutions (DFIs), each covering a particular area of activity or activities (Ofanson, Ukinamemen and Agbadua (2013). It performs the core function of financial intermediation, adequate payment services as well as the fulcrum for monetary policy implementation.

The Nigerian financial system has undergone several evolutionary stages ever since the independence of the country; foundation phase, Expansion phase, Consolidation and Reform phase. The phases marked different epochs in the evolution of the financial system.

1.1 Foundation Phase

This phase focuses on the establishment of institutions and development of necessary legislative framework. The phase is approximately from 1950 to 1970 . During this period, the Central Bank of Nigeria (CBN), the apex regulatory authority in the Nigerian financial sector was established. The CBN derives its legal authority from the CBN Act No. 24 of 1991 (Amended in 1997, 1998, and 1999) and the Banks and Other Financial Institutions Act (BOFIA) No. 25 of 1991 (Amended in 1997, 1998 and 1999) and presently the CBN Act 2007, which preceded the CBN Act of 1958 and Banking Act of 1969.

\subsection{Expansion Phase}

The expansion phase was directed at availing the public of banking activities and this was facilitated by the increase in network of branches. This involves the expansion of banks branches into the rural and semi urban areas. The phase also witnessed priority lending to some sector of the economy. This phase takes approximately from $1970-1985$.

1.3 Consolidation and Reform Phase

The Structural Adjustment Programme (SAP), which started in 1986, marked an era in Nigeria's financial sector reform. The monetary authorities relaxed the control and liberalize the sector. There was a deregulation of the economy and many institutions were set-up to regulate the growing financial sector. For example, there was the establishment of Nigeria Deposit Insurance Corporation (NDIC) in 1988, the Security and Exchange Commission (SEC) though established by SEC Act of 1979 but was further strengthened by SED Act of 1989 and Investment and Securities Act No. 45 of 1999.

Financial Sector Reforms

A peculiar feature of the reform program in Nigeria is the associated inconsistency in policy implementation. The financial sector in Nigeria is dominated by the banking sector, especially the commercial banking. The deposit money banks (DMBs') accounts for 93.0 per cent of non-central assets in 2000 (World Bank, 1995) and 94.0 and 95.2 per cent of the aggregate financial savings in 2002 and 2003, respectively as well as above 60.0 per cent of the stock market capitalization. Commercial banking started in 1892 with the establishment of the first banking firm, Standard Bank of Nigeria Ltd (now First Bank). Since then, the number of commercial banks has exploded. Thus, an understanding of the structural changes in the financial sector as a whole is of great importance to all stakeholders; as it would help in designing appropriate legislation to enhance competition. The Nigerian banking system has undergone remarkable changes over the years, in terms of the number of institutions, ownership structure, as well as depth and breadth of operations. These changes have been influenced largely by challenges posed by deregulation of the financial sector, globalization of operations, technological innovations and adoption of supervisory and prudential requirements that conform to international standards. Prior to the reforms started in 2004, the Nigerian banking sector was still weak and fragmented, often financing short-term arbitrage projects rather than productive private investments [Kanayo \& Micheal, 2011]. In essence all these measures and reforms were instituted to address the challenges of the banking sector and this shows that there are numerous challenges faced by the banking sector.

This study observe that there is a scarcity of literature on the challenges faced by Nigerian banks and therefore intends to explore and investigate the challenges faced by Nigerian banks and the way forward to address those challenges. The objective of this paper is to examine the challenges faced by Nigerian banking sector and proper solutions to the challenges.

To achieve the objective the null and alternate hypothesis were formulated

- That the challenges faced by the Nigerian banking system affects their financial performance

- That the challenges faced by the Nigerian banking system does not affects their financial performance

2. Literature Review

2.1 Challenges Faced By the Nigerian Banking Sector

Myriad of challenges exists and are currently affecting the efficacy of operations of the Nigerian banking sector to effectively perform their functions of intermediation in the Nigerian economy.

The major challenges faced by the Nigerian banks are as follows:

2.1.1 Inadequate Technological Innovation in operational services

The Nigerian banking sector market was hitherto dominated by competitiveness nature. The financial market in general was competitive because not only banks provide financial services other financial institutions that are not banks also do. There is fierce competition in the market hence the need for banks to acquire and deploy up to 
date ICT tools in their operations in order to capture the attention and loyalty of the customers. [REF XXX] Thus in the face of the keen competition in the industry, market players must devise new survival strategies. Financial institutions world-wide are compelled by the emergence of information technology to fast-forward to more radical transformation of business systems and models. It is in the same spirit that Bill Gates (2001) noted that:

\author{
"The successful companies of the next decades will be the ones that use \\ digital tools to re-invent the way the work. These companies will make \\ decisions quickly, act efficiently and directly touch their customers in \\ positive ways. Going digital will put on the leading edge of the shock \\ wave of change. That will shatter the old ways of doing business".
}

We are now in a new era of technological revolution. Countries are beginning to compete and fight over control of information rather than natural resources. The vogue today is E-platform which implies offering financial services through electronic media to various customers irrespective of place, time and distance. A customer friendly environment with high quality service delivers needs to be created in order to enhance high patronage. To this end, improvement in banking technology and institutional arrangements for transmission mechanism as well as other operational areas of banking operations to ensure operational efficiency has become a compelling necessity. This encompasses electronic money, internet banking, telephone/mobile banking, reduction of cash transaction, smart card. ATM transactions and capacity to process high volume of transactions among others.

2.1.2 Human resources management

The centrality of the human resource in enterprise management is a generally accepted dictum. It is in this light that management needs to make adequate investment in human factor. It should be noted that there is no competitive weapon more potent and effective in the banking sector than the quality of its human resources. As remarked by Sanusi (2010) machines and advanced technology can provide informational and transactional convenience but only manpower can provide the credibility, creativity and care that can build long-term customer and client relationships. In other words, there is need for capacity building in our system to enable us copes with the wind of technological development. Besides, no matter how accurate or competent a computer is, it cannot feed itself with input and it can neither offer a welcoming smile nor a warm handshake (Ochejele, 2003). Banking (and indeed the entire sectors in the financial markets) is people-related and the quality of personnel will make the vital distinction between what constitutes a good bank and a bad one. Consequently, of all the challenges facing the Nigerian banking sector, human capital development is the most daunting.

2.1.3 Fraud prevention and monitoring system

Another major challenge facing the industry is the need to minimize the high rate of frauds and other malpractices in the system. It is imperative that bank managers and other market players give greater attention to the subject of maintaining the highest ethical and professional standards in all their transactions and dealings with their customers. This entails having adequate knowledge of Code of Conduct and Banking Practice jointly designed by the Chartered Institute of Bankers (CIBN), Central Bank of Nigeria (CBN) and the Bankers Committee (General Assembly of Bank Chief Executives). Issues of business integrity, respect for legitimate laws and regulations, concern for the society in which a bank operates will become as much important as profit consideration in the $21^{\text {st }}$ century. The level of malpractices in the banking sector is high, hence there is need to put measures in place to curtail the malpractices to the bearest minimum.

2.1.4 Liquidity management

While it is expected that there will be more external resource inflow to fund growth of the economy in this country, financial institutions must recognize their primary role in internal resource mobilization. It is assumed that the economy is awashed with liquidity and substantial portion of this liquidity is held as idle cash balances outside the banking system. The business of resource mobilization should therefore be seen as a major challenge facing the banking sector. In addition to internal mobilization of funds, banks must also ensure effective channeling of these resources to productive segments of our economy. The responsibility of promoting the economy's growth should be seen as a major challenge by all banks. Fund mobilization and allocation should therefore form a top priority of banks chief executive officers policies in this country.

2.1.5 Full autonomy of the Central Bank of Nigeria

The turnaround of the banking sector and indeed the economy would be difficult without an institutional and operational autonomy of the Central Bank of Nigeria (Ekundayo, 1996). The current situation where the apex institution is only given nominal autonomy which it cannot exercise effectively is not very healthy for the banking sector. The CBN should be given a leverage to establish its authority over its traditional area of jurisdiction. It is only with such authority that the apex institution will be able to formulate viable monetary policies and offer advisory services to the Federal Government on financial matters. To this, may be added the need for internationalization of the Nigeria capital market in spite of the malpractices in the market, the Nigerian Stock Exchange (NSE) has been intensifying efforts at encouraging cross-border listings. The NSE is reported to 
have signed a memorandum of understanding each with the Nairobi Stock Exchange, the Ghana Stock Exchange and the Johannesburg Stock Exchange NSE should endeavour to fight the malpractices to accentuate the internationalization of the Nigerian capital market.

\subsubsection{A Need to Uphold Ethics and Professionalism in the Banking Sector}

Ethics generally revolves around a set body of values, reformative guidelines and principles that embellish an individual with a sense of judgment and differentiation of right from wrong. There is need to adhere to the ethics and professional practice guiding the sector by the players in the banking sector. This is so and it supposed to be from ordinary banks staff to the management staff. Currently there is high level of unethical behaviours in the banking sector as evidence by the activities of marketers in the banking sector. It is in this context that this study view with serious concern the spate of ethical misconduct, unprofessional use of female staff in some banks in the name of 'marketing' and 'sourcing of funds, falsification of returns by the banks to the Central Bank, etc. Collectively, the stakeholders can stop these misconducts and give the system a new face. In recent times, the Central Bank of Nigeria has been intervening to investigate fraud, greed, insider abuse, etc. These were the succeeding results of unethical behavior from both bank staff and management. Unethical behavior is responsible for distress in banks. And apparently, punishments for these unprofessional behaviors are trivial.

2.1.7 Poor corporate governance practices

In the banking sector, proper governance is vital for improvement of company performance, attraction of investors and numerous more benefits. Whistle blowing and business ethics which can be encouraged through moral corporate governance, would undoubtedly lead to reduction in fraud in money deposit banks. Unfortunately, a substantial number of Nigerian banks lack moral corporate governance practices. The new code of corporate governance for banks is sufficient to minimize bank distress. But do banks adhere to this? Most of the banks do not actually adhere to corporate governance practice and there is need for them to see this as a serious challenge facing the sector. To function more effectively and efficiently banks should embrace the corporate governance issue as soon as possible.

2.1.8 Reliance on public sector funds

Most banks have abandoned the private sector in their chase for government funds. Heavy dependence on the public sector, crowds out the private sector from the economy. Consequentially, the Central Bank of Nigeria released a policy on the increment of cash reserve requirement for public sector. With the implementation of this policy, most banks began to source for income in the private sector

\subsubsection{Implementation of the TSA Treasury single account}

The treasury single account is a financial policy used in several countries all over the world. Like other third world countries, it was introduced by the federal government of Nigeria in 2012 to consolidate all inflows from all agencies of government into a single account at the Central Bank of Nigeria. But the previous government lack the political will to implement the policy until the coming of APC government in 2015 were TSA policy was implemented and it is yielding positive result in the economy as currently over N6 Trillion was save under TSA.

This system establishes a unified structure as advised by the International Monetary fund where all government funds are collected in one account as this would reduce borrowing costs, extend credit and improve government's fiscal policy, among other benefits.

\subsubsection{Insecurity and Bank Fraud}

Fraud according to Adeniji (2004) and Asuquo (2005) is an intentional act by one or more individuals among management, employees or third parties which results in a misrepresentation of financial statement. The issue of insecurity and fraud in the banking sector is an interruption to the roles banks play towards economic development of the country Clementina, \& Isu, [2016].

The increasing incidence of insecurity and frauds affect the already survival and viability of the banking sector. Fraud is not unique to the banking sector but due to the product which the banks deal on - cash and Nigeria is cash based economy, no area of banking system is immune to fraudsters, not even the operational security. The characteristic of this economy is that the cash will be physically held and touched. In Nigeria, studies indicate that more than $90 \%$ of funds are outside the banking sector as against the developed world where the money in circulation is 4\% and 9\% in the UK and US respectively. This explains the reason for the fragile nature of our banking system. The increasing rate of insecurity and fraud in the banking system, if not address might pose serious threats to the stability and the survival of individual banks and the performance of the sector as a whole (Nwankwo, 1991). Lamenting on the ugly impact of insecurity and fraud in banks, Saludo (2004) said that fraud has left untold hardship on the lives of bank owners, staff, customers and family members as most bank failures are always associated with large scale of frauds. Bank fraud may take any of the following form:

- Suppression of cash lodgments

- Forgeries of signatures

- Abuse of IOU's

- Un-authorized lending 
- Fraudulent use of bank documents

- Over-invoicing of purchases among others

- Fraudulent loans

- Forgery and altered cheques

2.1.11 Poor Internal control system mechanism

Often times the internal control of many banks is not allow to functions well due to management interference.

2.1.12 Restriction on foreign currency capital transactions

There are many restrictions on the commercial banks on foreign currency transactions and this do not allow banks to actually get involve on the issue of foreign currency at ease and therefore create a hindrance for the banks to fully have a say on the foreign currency transaction in the country and create a big challenge for the banks to satisfy their customers that deals with foreign transactions especially the demand of foreign currency for importers and the issue of BTA.

2.1.13 Need to access banking services at lower costs (only possible if industry costs are lowered)

This is another challenge because customers want to always access banking services at possible lowest cost, in fact a customer want to have banking service at zero cost if possible. This is actually not possible because banks are in business to make profit and satisfy shareholder needs. It is actually a challenge for the banking industry but they can minimize the operation cost to ensure that customers access banking services at lowest possible cost.

2.1.14 Poor Cost Control/Cost Reduction

Most of the Nigerian banks are not embracing cost control in terms of their spending culture. Banks themselves and the staff are flashy in life and are not actually cutting costs that supposed to be reduced. Example the use of exotic and flashy official vehicles by banks; this cost can actually be cut down if the banks can revert to using average cars for official purpose.

2.1.15 Large Percentage of Non-Performing loans

Defaulters are many, ranging from corporate defaulters to individuals defaulters and most of the defaulters are not having substantial security where the banks can easily rely on to recover their money. There is presence of non-performing loans and this has adversely affected the financial performance of the banks and consequently affects the benefits of the shareholders in terms of the dividend that is to be provided.

2.1.16 High Cost of Doing Business in the Environment

The cost of doing business in Nigeria is still high when compared with developed economies or some emerging and developing countries owing to the poor state of infrastructure.

2.1.17 Challenge of Inadequate FX for Customers

Customers find it difficult to get foreign currencies from their banks especially dollars, euro and pounds sterling, banks in Nigeria are struggling to source FX for imports to their customers as a result if fail to meet FX for customers tends to lose some of their important customers.

2.1.18 Violations of The Banking laws, Rules and Regulations as Reported By The NDIC

Nigeria has the fastest growing banking system in Africa, and one of the fastest in the world, but the violation of the banking laws pose a serious challenge to this development Charles Soludo [2004]. Banks most often violates Money Laundering (Prohibition) Act, 2004 to satisfy the needs of their customers especially the rules pertaining to "Know Your Customers" (KYC) requirements and the cash transfer limits.

2.1.19 Granting Credit Facilities In Excess of Specified Single Obligor Limits

Some of the Nigerian banks are still violating the credit guidelines of the specified amount to be granted to the single borrower and this pose a serious challenge to the banking operation and the going concern of the bank.

\subsubsection{Investments in Subsidiaries without CBN Approval and Violation of Corporate Governance Practice}

Some banks had turned their various subsidiaries into vehicles for circumventing regulatory requirements. For instance, some banks engaged in financing highly risky business activities including speculative trading in stocks and shares through their respective subsidiaries. In fact, the $\mathrm{CBN}$ reveal that banks total exposure to Capital market as at January, 2009 was N784 billion. Presently some banks have various weaknesses in Corporate Governance. Some of them were yet to imbibe the tenets of the Code of Corporate Governance issued by the CBN in 2006. Example of some critical corporate governance issues includes non-performing-insider-related debts, board oversight was weak in some of the banks, in some instances, the Boards had assigned the responsibility of vetting big ticket transactions to their respective credit committees that were often dominated by the executive directors. Others are investing in subsidiaries without CBN approval, failure to appoint independent directors etc.

\subsection{Solutions to the Challenges of the Nigerian Banking Sector}

2.2.1 Improvement in Financial and Regulatory Reporting

Proponents of banking globalization refer to the multitude of banking crisis during the last two decades and point to the weaknesses of the regulatory and supervisory environment in many emerging markets. 


\subsubsection{Immediate Stoppage of Capital Flight to Foreing Banks}

The fact that international banks are perceived to be sounder than local banks in times of crisis has led some to argue that foreign bank presence opens the possibility of a capital flight at home. Before the appearance of foreign banks, investing abroad was the only safe haven for domestic depositors, given the lack of credible deposit insurance. Now, under the assumption that foreign banks are strong enough to withstand a crisis, all depositors need to do is transfer their savings from local to foreign banks.

\subsubsection{Globalization of the Nigerian Capital Market}

There is need to open up the Nigerian capital market for foreign investors and foreingn companies to list their shares. By such doing it will give way for foreign investors to have interest in buying the shares of Nigerian banks and consequently generates capital flow in to the banks and makes the bank to get more stronger.

2.2.4 Acquisition and Deployment of Latest Technological Innovation on Banking Business

Nigerian banks need to embrace information technology. This is one of the preconditions for a nation to be integrated into the global financial market and reap the benefit therefore, banks must train their staff in e-banking which has the advantage of reducing cost of transactions and increasing the speed of transaction and profitability. There is need for strengthening the regulatory and supervisory institutions and strict implementation of Money Laundering Laws and other legislation laws to effectively tackle fraud and fraudulent activities: upward review of capital market deregulation and introduction of indirect monetary policy instruments. The regulatory bodies in the financial markets such as the Central Bank of Nigeria (CBN) and Securities and Exchange Commission (SEC) should be granted complete autonomy. This will enable them fight the malpractices in the system and also formulate viable monetary policies that will insulate the financial markets and the economy at large against domestic and external macroeconomic shocks. Recent developments in the banking sector, including increased signs and incidence of distress, are a cause for serious concern and call for decisive and expeditious actions to safeguard the stability and soundness of the banking system. Legal and regulatory enforcement is needed to ensure action is taken against those that violate their prudential and financial obligations, and to act as a credible deterrent for all market participants [Kanayo \& Micheal , 2011] there is need for banks to offer better banking services through diversified delivery channels to customers: Banks should be customers focus. There is need for banks to imbibe the culture of cost control

There is need for banks to imbibe the culture of ethics and professionalism Strict Compliance to effective corporate governance Prevention of Fraud and Insecurity in Banks:

It is also necessary to carry out audit checks on all transactions as soon as they are made because delay might have dire consequences on the bank. Similar checks should also be carried out on vouchers raised for expenses (printing, stationeries, stock, office equipment etc.) Market surveys should be conducted before approvals are given for the purchases. Members of the Board of Directors should not just be people, who have stakes in the banks but should be knowledgeable in banking and accounting, to enable them carry out their supervisory role effectively. There should be Greater Transparency and Accountability in Banking Operation.

These measures, we believe, will help to reduce the increasing rate of fraud and acts of insecurity in Nigerian banking sector.

\section{Methodology}

The population of this study comprises of all the twenty four (24) commercial banks quoted by the Nigerian stock exchange (NSE). Bank qualify only to be one of the sample of this work if it has a branch in Bauchi state metropolis because of the limited time for the research work and the paucity of resources to be employed to conduct this study. The application of these conditions results in the emergence of fifteen (15) Banks as the sample of the study, which include: First bank of Nig Plc, PolirisBanK Plc, Keystone Bank Plc, Guarantee Trust Bank Plc, Diamond Bank Plc, Sterling Bank Plc, Access Bank Plc, United Bank of Africa Plc, Stanbic IBTC Bank Plc, Heritage Bank Plc, Union Bank Plc, Unity Bank Plc, Zenith Bank Plc and Wema Bank Plc. The study employed the use of Questionnaires of each of the business development officers [BDM] of the each main branch of the banks and two other operation staff of the banks were engage to fill the questionnaires which includes BDM on the challenges facing the bank. The data were analyzed using the chi-square [x2] method of analysis and the result was presented with the explanation of the analysis.

3.1 Research Instrument

In order to have a comprehensive and reliable source of information, strictly structured questionnaires were administered to respondents in the selected banks to obtain information on the challenges facing Nigerian banks. The questionnaires is divided into two parts, Section A is related to demographic information and section B consist of questions (Yes or No questions) relating to the subject of the study. Chi-square was used to analyzed data and this include simple percentages, the use of percentages was very much recommended by Asika, (2004).

Simple percentage is given by $=\underline{\text { Number }} \times \underline{100}$

$$
\text { Total } 1
$$


i. Chi-square $\left(\mathrm{X}^{2}\right)$ is given by the formula $\mathrm{X}^{2}=\sum_{1=i}\left(\frac{f \circ-f e}{f e}\right)$

ii. Where: $\mathrm{X}^{2}=$ chi-square $\Sigma$ =summation $\mathrm{Fe}=$ expected frequency $\mathrm{Fo}=$ observed frequency and fe (expected frequency) is given by= (row total $\mathrm{X}$ column total)

iii. The degree of freedom necessary for the application of chi-square $\left(\mathrm{X}^{2}\right)$ is determined thus; $\mathrm{df}$ $=(\mathrm{r}-1)(\mathrm{c}-1)$

Where: $r=$ number of rows. $c=$ number of columns

iv. The level of significant used is 0.05 or $95 \%$

v. Decision rule: To reject the null hypothesis if the calculated chi-square $\left(\mathrm{X}_{e}^{2}\right)$ is less than the tabulated chi-square $\left(\mathrm{X}_{t}^{2}\right)$. Thisis, if $\mathrm{X}_{c}^{2}<\mathrm{X}_{t}^{2}$ reject $\mathrm{H}_{\mathrm{o}}$ and accept

$\mathrm{H}_{+}$.

3.1 Testing Hypothesis

In testing the hypothesis, the chi-square $\left(\mathrm{X}^{2}\right)$ test was employed, this is because it could be used for both small and large samples. The chi-square test is a measure of the discrepancies exiting between the observed frequencies and expected frequencies of one or more variables.

i. Ho: That the challenges faced by the Nigerian banking system affects their financial performance

ii. $\mathbf{H}_{1}$ : That the challenges faced by the Nigerian banking system does not affects their financial performance

In line with the hypothesis question, question 2 of the questionnaire was used to test the hypothesis and the responses are as follows:

Table 1. Contingency Table for Testing of Hypothesis

\begin{tabular}{llll}
\hline OPTIONS & Number of respondents & Total \\
\hline & Operation Staff & $\begin{array}{l}\text { Business } \\
\text { Development } \\
\text { Officer }\end{array}$ & \\
\hline Yes & 23 & 12 & 35 \\
\hline No & 5 & 2 & 7 \\
\hline Total & 28 & 14 & 42 \\
\hline & & Source: Survey 2018
\end{tabular}

The table 1. above shows that a total of 42 questionnaires were retrieved out of the 45 questionnaires distributed and the 3 that were not accounted in the table are invalid for the analysis.

Computation of the test using the chi-square $\left(X^{2}\right)$

$$
\begin{aligned}
X^{2} & =\sum_{1=i}\left(\frac{f \circ-f e}{f e}\right) \\
& =\frac{35 \times 28}{42} \\
& =23.33 \\
& =\frac{7 \times 28}{42} \\
& =4.66 \\
& =\frac{35 \times 14}{42} \\
& =11.66 \\
& =\frac{7 \times 14}{42} \\
& =2.33
\end{aligned}
$$

\begin{tabular}{|c|c|c|c|c|}
\hline \multirow[t]{2}{*}{$\overline{\mathrm{OF}}$} & \multirow[t]{2}{*}{$\overline{E F}$} & \multirow[t]{2}{*}{ (OF-EF) } & \multirow[t]{2}{*}{$(\mathrm{OF}-\mathrm{EF})^{2}$} & $(O F-E F) 2$ \\
\hline & & & & $E F$ \\
\hline 23 & 23.33 & 0.33 & 0.66 & 0.0283 \\
\hline 5 & 4.66 & -0.34 & -0.68 & -0.1456 \\
\hline 12 & 11.66 & -0.34 & -0.68 & -0.0583 \\
\hline 2 & 2.33 & 0.33 & 0.66 & 0.2832 \\
\hline
\end{tabular}

4. Analysis and Discussion of Results Table 2. Chi-Square Table for testing hypothesis 
0.66

$$
\begin{gathered}
\mathrm{X}^{2}=\sum\left(\frac{O F-E F}{E F}\right) \\
\mathrm{X}_{c}^{2}=0.108 \\
\mathrm{X}_{t}^{2}=3.841
\end{gathered}
$$

While taking @ ( level of significance) $=0.05$

Degree of freedom $=1$

\section{Decision}

$3.841>0.108$

From the above- calculated chi-square $\left(\mathrm{X}_{e}^{2}\right)$ is 0.288 which is less than the tabulated Chi-square (

$X_{t}^{2}$ ) 3.841. i.e. $X_{c}^{2}<X_{t}^{2}$.

Since the calculated Chi-square is less than the tabulated Chi-square we can now reject the null hypothesis which says the challenges faced by the Nigerian banking system affects their financial performance and accept the alternate hypothesis which says the challenges faced by the Nigerian banking system does not affects their financial performance

4. Results and Discussion

This section presents, analyses and interpret the results obtained from the generated data of the questionnaire.

4.1 Summary of Findings

This research work study the challenges of the Nigerian banking sector and the way forward. Banking sector in Nigeria is a very important key to driving the economic activities apart from their role of financial intermediation, they also provides a lot of employment opportunities to the citizens of the country. As such the challenges faced by them should be squarely address by the government and the regulatory authorities to improve their contribution to the nation economy.

Even though, the findings revealed that, the challenges faced by the Nigerian banking sector does not affects their financial performance. However, efforts should be in place to addressed those challenges identified in the study.

5. Conclusion and Recommendation

This study concludes that banking sector challenges in Nigeria do not affect the financial performance of the banks, but care and necessary support both in terms of policy and operational support should be given so as to improve their contribution to the Nigerian economy. The study recommends that government and relevant regulatory agencies should put heads together to render support and address those challenges identified that affect the sector. also Nigerian banking sector should invest in both technological innovation and human capital development, they should imbibe the culture of good corporate governance and stick to the issue of banking ethics and professionalism among others.

References

Adeniji, A.A. (2004). Auditing and Investigations, Lagos: Value Analysis Consult.

Asika, N. (2004). Research Methodology in the Behavioral Science, Lagos Longman Nigeria, Limited.

Auquo, B. E . (2007). Microfinance And Public. The Nation, May 18,2007. Pg 16

Clementina, K., \& Isu, I. G. (2016). Security challenge, bank fraud and commercial bank performance in Nigeria: An evaluation. Journal of Business and Management, 5(2), 1-21

CNBC Africa Nigeria 6th Floor (East \& West Wing), South Atlantic Petroleum Towers, 1 Adeola Odeku Street, Victoria Island, Lagos State Nigeria.

Ekundayo, B.I. (1996). Financial And Real Sector Interactions In Developing Economies: The Case Of Nigeria. A Paper Submitted To African Development Finance Policy Workshop For Consideration in The Workshop.

Kanayo and Micheal (2011) Foreign Portfolio Investment and Economic Growth in Nigeria.international Journal of Business and Social Science. (5) 11, 1-14

Nwankwo, G.O. (1991). Bank Management, Principles and Practice. Malthouse Press Ltd.

Lagos

Ochejele, J. J. (2003) .The Nigerian Financial Market and the Challenges of the Twenty First Century. Unpublished Paper.

Ofanson E. J. Ukinamemen A. A. And Agbadua O. B. (2013) Assessing The Impact Of Banking Reforms On The Performance Of The Banking Industry In Nigeria . Indian Journal of Commerce \& Management Studies. (4) 2, 2240-0310 
Sanusi, L. S. (2010). The Nigerian banking industry: What went wrong and the way forward. Being an address delivered at the convocation Square.

Soludo, C. C. (2004). Consolidating The Banking Industry To Meet The Development Challenges of The 21st Century; Being An Address To The Special Meeting of The Bankers Committees Held On July $16^{\text {th }}$ 2004 At The CBN Headquarter Abuja.

Uche Basil Onwe [2013] The Nigerian Financial Market And The Challenges Of Information TechnologyBased Operational Services. Kuwait Chapter of Arabian Journal of Business and Management Review. (2) 6

World Bank (1995). World development report 1995, Washington

\section{Copyrights}

Copyright for this article is retained by the author(s), with first publication rights granted to the journal.

This is an open-access article distributed under the terms and conditions of the Creative Commons Attribution license (http://creativecommons.org/licenses/by/4.0/) 